\title{
A process approach to the open green space system planning
}

\author{
Berfin Şenik ${ }^{1} \odot$. Osman Uzun ${ }^{1}$
}

Received: 20 June 2021 / Revised: 27 November 2021 / Accepted: 10 December 2021 / Published online: 27 January 2022

(c) International Consortium of Landscape and Ecological Engineering 2021

\begin{abstract}
Open green spaces have significant contributions to the city, urban residents and ecosystem. However, these contributions could not be fully reflected on the urban space due to rapid urbanization. Furthermore, studies on this reflection have focused only on a specific function of open green spaces without a holistic approach. Also, there is no common framework for the definition, classification and standardization of open green spaces or a comprehensive analysis of these domains. The present study aimed to propose a guideline that included five criteria to serve as a baseline to plan open green space systems. In the study, open green spaces and the city were considered as a subsystem of the landscape. Thus, open green space objectives and strategies were proposed based on the landscape functions, urban character and urbanization level (urban density). Furthermore, the study reconsidered the definition and classification of open green spaces and recommended standards. These standards were categorized in two groups based on recreational standards and natural disasters. Thus, the open green spaces were analyzed based on qualitative, quantitative, connectivity and location selection criteria with a holistic approach and a multi-dimensional framework was developed based on ecological, recreational and disaster criteria.
\end{abstract}

Keywords Landscape function · Urban character · Degree of urbanization · Open green space

\section{Introduction}

Global urban population has been increasing rapidly since 1950 , and $30 \%$ of the world population lived in cities in 1950 , while $54 \%$ were urban dwellers in 2014, and it is predicted that urban population will be $66 \%$ in 2050 (United Nations 2012). The direct correlation between urbanization and population growth and the emerging new urban settlements has gradually limited access to nature, several ecological problems now require the reconsideration of the urban environment to provide healthy and sustainable living conditions (World Health Organization 2017). On the other hand, interconnected open green spaces has been significant for the redefinition of the relations between the nature and the city for "health and wellbeing" (Fuller et al. 2007; Threlfall et al. 2016), contribution to climate balance at the urban scale (Bowler et al. 2010; Vieira et al. 2018), providing a habitat for and contributing to biodiversity (Aronson et al. 2017), serving as a assembly point for the recreational

Berfin Şenik

berfinsenik@duzce.edu.tr

1 Faculty of Forestry Department of Landscape Architecture, Duzce University, Konuralp Campus, Merkez/Duzce, Turkey needs of the society and providing social interaction (Peters et al. 2010), and serving as an assembly point and a shelter during or after natural disasters (Zhu et al. 2016).

In recent years, the determination of the plans and strategies to maximize the contribution of open green spaces to urbanization has been prominent. The advances in modern planning led to the development of quantitative measures and standards for open green spaces to describe urban space density and attraction (Ståhle 2010). In late 1800s, Ebenezer Howard's garden city model in England and Frederick Law Olmsted's idea of a large urban park and park system in the USA provide models where more green spaces were integrated into urban environment to create livable urban spaces in response to the environmental impact of the cities (Jim and Chen 2003). The first parks aimed to serve as spaces of leisure, recreation and integration with nature (Cohen et al. 2016). The initial open green space standards were proposed in the early twentieth century, and Bartholomew and Associates run by Olmstead, the landscape architect who planned several American parks, stated that any urban resident should be no further than $400 \mathrm{~m}$ from a park. Similarly, approximately 2.4 ha of green space was proposed for 1000 urban residents in the United Kingdom in the 1920s. In the 1940s, about 3.0 ha of green space standard for 1000 
urban residents was introduced in Australia. Over the years, open green space standards have been ratified based on the changes in requirements (Byrne and Sipe 2010). Today, the green space standard published by the United Nations is 30 $\mathrm{m}^{2}$ per capita, the European Union standard is $26 \mathrm{~m}^{2}$ per capita, the USA (determined by the Public Health Bureau and the Department of Housing) is $18 \mathrm{~m}^{2}$ per capita, the World Health Organization standard is $9 \mathrm{~m}^{2}$ per capita. Access (walking distance) to open green spaces was determined by the European Environment Agency as approximately (maximum) $1000 \mathrm{~m}$ (15 min walking distance), and by English Nature as (maximum) $300 \mathrm{~m}$ (Khalil 2014).

Although standardization of open green spaces is important, the condition of the existing standards has been seriously criticized (Harding 2000; Pauleit et al. 2003). The concept of green space in urban planning has been addressed based on 'quantity' in urban landscape; however, an approach based on only quantity does not adequately reflect the functions of green spaces to sustain biodiversity (Sandström et al. 2006). Baycan-Levent and Nijkamp (2009) similarly indicated that the quantity of green spaces has been determined by the standards; however, these standards did not address the quality and management of green spaces. Marriott (1999), on the other hand, claimed that these standards were not scientific and did not reflect various components such as cultural, demographic structural or physical and environmental diversity. Finally, the ecological function of open green spaces (providing a habitat, improvement of biodiversity, etc.) depends on adequate size, density, number and connectivity of these spaces (Forman 1995a). Similarly, according to Heidt and Neef (2008), when improvements in urban ecological and environmental quality are an important goal, an integrated approach to strengthen the green network system should be kept on top of the priorities in planning. Thus, development of urban green space networks includes the preservation of existing green spaces, the development of new spatial forms, and the restoration/rehabilitation and maintenance of the connections between various green spaces (Kong et al. 2010).

The conceptual framework of the open green spaces is also different in several studies. This led to several definitions and classifications about the open green spaces. For example, certain studies employed separate terms such as open space (Acharya and Bennett 2001; Alabi 2020) or green space (Jim 2004; Wolch et al. 2014), while others utilized the terms open green space (Singh et al. 2010; Mpofu 2013) or green open space (Cho et al. 2008; Mell 2020). Furthermore, studies defined the concept with different definitions. For example, according to the Open Space Strategy (City of Melbourne Administration 2012) developed for the city of Melbourne, open spaces are defined as public spaces such as parks, gardens and waterways reserved primarily for recreation, conservation of nature, and assembling of urban residents. According to Dunnet et al. (2002), open spaces are areas that contribute to the visual urban landscape and quality of life as a part of the urban space, have public access, and combine urban and green spaces. These definitions reflected that open spaces are both public and green spaces. Similarly, Li et al. (2017) described urban green space as a type of open space that includes grass, trees, flowers, water and certain required infrastructural elements. However, according to Tzoulas et al. (2007), the urban green space network includes public spaces (streetscapes, remnant nature reserves, public parks, etc.) and privately owned areas (golf courses, residential gardens, etc.). In addition to the public character, in some definitions, it was observed that the concept acquires a "recreational" content which is also reflected in the classification. For instance, according to Lynch (1981), open spaces could be categorized in six classes: regional parks, urban parks, squares and plazas, linear parks, children's playgrounds, sports areas, empty lots (where children can play) and adventure playgrounds. The definitions differ based on the recreational function and publicity. Due to the lack of a consensus on the concept and the requirement of resolving this problem, a meaningful definition should be developed based on a qualitative and quantitative approach (Taylor and Hochuli 2017). In the present study, the concept of open green space was adopted.

On the other hand, Randolph (2004) classified various processes associated with open green space planning as pre-1980 park and recreation planning, open space planning in the 1980s, greenway and open space planning in the 1990s, and green infrastructure in the 2000s. According to Benedict and McMahon (2006), green infrastructure is a natural life support system consisting of waterways, wetlands, forests, wildlife habitats, etc., that contribute and connect to the continuity of ecological processes and natural cycles and the quality of life of society. The origins of the concept are based on Howard's Garden City Movement, Little's greenways and Jongman and Pungetti's landscape ecology studies (Mell 2017). In terms of its physical structure, green infrastructure consists of hubs, sites and links (Mejía et al. 2015). Therefore, the emerging concept of the green infrastructure has been directly associated with open green space system planning (Sandström 2002). Whether it is called green infrastructure or open green space network, the basic concept is to adopt the system approach regardless of the urban-rural divide. The system approach, which emerged in the 1950s and could be applied in various disciplines such as ecology and sociology, entails a configuration that includes interrelated parts (components) within a network of relationships to serve a specific purpose (Jackson et al. 2010). A holistic systemic approach facilitates the development of solutions. Thus, it is important to define the objectives of the system, the subsystems, the correlations between the subsystems and 
the whole system (Lai and Huili Lin 2017). Previous studies revealed the relational network, processes and components of ecosystems based on the approaches described as socio-ecological systems or human social system-resource systems (Pickett et al. 1997; Alberti 2008) and these studies indicated the systemic structure of the urban-ecosystem relationship. This relational network (chain reaction) described a system revealed by the concept of landscape by collecting concepts such as land-use, land cover, population growth, human behavior, topography, natural cycles, and biodiversity. Because the landscape is a mosaic that includes ecosystems that interact with each other and exist within the realm of exogeneous effects (Forman 1987; Forman 1995b), and all natural and cultural components. Thus, if the landscape is a system, open green spaces and cities are its subsystems. Therefore, it is important to construct an open green space system that defines the structure, functions and processes included in the landscape, supports the sustainability of the landscape, and articulates urban interactions.

The present study aimed to develop a process approach that define and classify an open green space system within the landscape, examine the qualitative, quantitative, interconnection and location criteria that would lead to an open green space system, analyze and formulate strategies about the relationship between the open green space system and the city, and develop ecological, recreational and disasterbased goals and standards to allow the multifunctional analysis of the open green spaces.

Based on the aims of the study, it was expected to contribute to the literature in the following areas:

(1) With the approach based on landscape as a system, open green space and cities as its subsystems, the conceptual content of the open green space system was expanded, and strategies that reflect the urban character and the urbanization level and are guided by both nature-human interaction and ecological and geomorphological processes were presented.

(2) A "holistic" approach was adopted through the analysis of the qualitative, quantitative, interconnections and location selection criteria, which have not been scrutinized with a holistic approach in previous studies.

(3) The concept of open green space was discussed with a broad approach and classified based on this broad definition and to complement the gaps in previous classifications in the literature. As part of this classification, open green space standards were proposed.

(4) Unlike approaches that were based on specific functions of open green spaces, strategies and standards were developed to help spatialize a multi-dimensional framework for ecological, recreational, and disasterbased criteria.

\section{Methods}

Previous studies in the literature focused on certain topic or topics such as the quality, quantity, access, systemic contribution, interconnectivity of open green spaces (Ahern 1991; Rudd et al. 2002; Van Herzele and Wiedemann 2003; Kong et al. 2010; Lee and Maheswaran 2011; Van Dillen et al. 2012). However, there is still no study that analyzed all these variables. It is necessary to develop a holistic framework rather than partial approaches to address open green spaces. A holistic and systematic approach is possible by revealing the conceptual content of open green spaces and their relationships with other systems of interaction. All open green space components and the systems that include these components or the subsystems they interact with essentially entail a hierarchical structure with a broad spectrum. This structure includes living being, communities, habitats, cities and their relationships. This hierarchical structure, described as the "levels of biological organization" (MacMahon et al. 1978), also offers a holistic approach to explain the systemic relationships between landscape, open green spaces, and cities. Thus, the methodology of the present study adopted the levels of organization approach that also included the landscape, and redefined by Barret et al. (1997) (Fig. 1).

In this approach, landscape includes natural ecosystems such as forests, streams, wetlands in the city and its immediate surroundings, and artificial ecosystems such as agricultural, residential, industrial, and commercial zones, etc. Here, landscape, corresponds to the basic system that includes the open green space system, urban systems, and the combination of natural and artificial ecosystems as a concept. In other words, it should be perceived as a biological system. Therefore, it is a multidimensional concept, and this feature is reflected on the subsystems. In urban systems, human influence is significant. Open green space systems could include all natural and artificial ecosystems (even urban systems). Thus, these two systems are directly interrelated based on natural (water, soil, geological structure, climate, flora and fauna) and cultural (land cover-land use, population, etc.) landscape components. The method was based on the framework of these relationship networks and was implemented through five consecutive steps.

1. Evaluation of the landscape function: This stage aimed to reveal the spaces with high-low landscape functions to measure the functionality of natural and cultural landscape elements in urban scale. At this stage, it was emphasized that open green spaces could be constructed in connection with the landscape functions (regulation, habitat, cultural, etc.), and this construct is of vital 


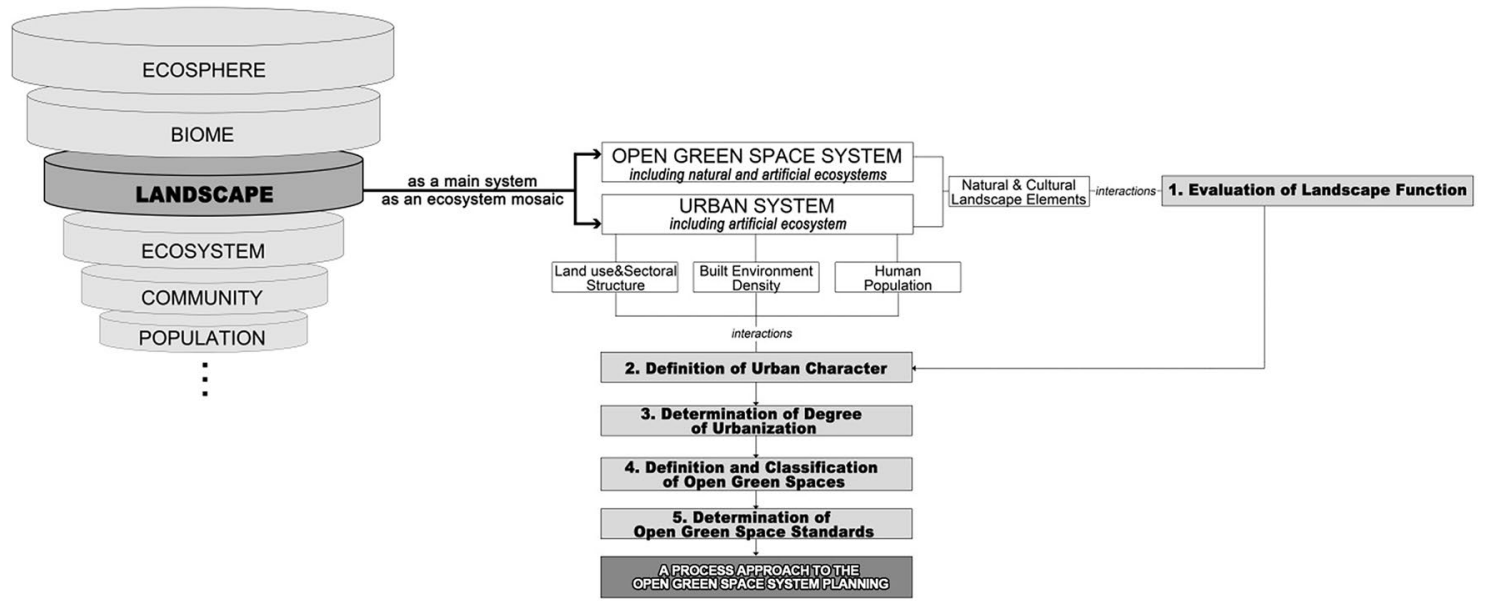

Fig. 1 Method

importance in shaping the urban future. The spaces that include significant natural landscape processes were included in the planning and design of the open green space.

2. Definition of urban character: The conceptual framework guided by the three components (land use and sectoral structure, built environment density, population) that describe the structure of the urban systems, including artificial ecosystems was defined. Strategies were proposed to address the open green spaces based on each urban character.

3. Determination of the degree of urbanization: Open green spaces are not distributed homogeneously in urban areas. The quantity and typology of open green spaces varies between the urban core and the fringe based on urban density and construction. In this stage, this structure and variations were defined, and certain recommendations were proposed.

4. Definition and classification of open green spaces: A holistic definition was developed by improving the qualitative and quantitative definitions of open green spaces, and new typologies adequate for this definition and supplement the classifications proposed in the literature were introduced.

5. Determination of open green space standards: Standards for open green spaces were developed, categorized and reconsidered based on urban requirements.

\section{A process approach}

\section{Evaluation of the landscape function}

Landscape includes abiotic and biotic structures and processes in an area, their relationships with human society and its components, and various patterns that result from these interactions (Turner 1989; Pickett and Cadenasso 1995; Farina 2008). Thus, it includes ecological and social factors and it allows the process approach to analyze the ecological and social benefits of open green spaces. It also defines a basic system and includes the sub-systems of open green spaces and urban landscape. Thus, cities could be considered as the most heterogeneous landscapes, and urban sustainability depends primarily on the maintenance of the landscape (Wu 2009). The stages in the process approach were essentially determined by the framework of the relationships between the open green spaces and the urban landscape. Changes in urban land cover and increase in the rate of impermeable surfaces alter water cycle functions (Wu 2008), lead to the fragmentation of habitats (Conway and Lathrop 2005), and increase erosion risk (Bakker et al. 2008). The consequences negatively affect the structure and function of the landscape; however, the integrity of the landscape could be restored by the introduction of an open green space system (Ahern 1991). Thus, the definition of the urban processes that disrupt the integrity of the landscape structure and functions is essential.

The landscape structure is defined as the composition and configuration created by landscape elements, including the landscape structure, patches of different scales, corridors and matrix, and the landscape function is defined as the horizontal and vertical flow and interactions between energy, species and nutrient landscape elements (Forman and Godron 1986; Ahern 1991; Hobbs 1997; Wu 2012). Landscape function analysis is an important tool to analyze the consequences (landscape function) of land use variations (landscape structure) (Golley 1987). Furthermore, it represents certain social values (aesthetic, or humanistic criteria) in the structure-function relationship (Ahern 1991). Function-based approach includes the 
harmony between landscape and human ecology (Hall 1991). Thus, the analysis of the total (landscape pattern) of all landscape elements (geological structure, climate, soil, water, flora and fauna, land cover-land use, human population, etc.) and the landscape composition (diversity and relative abundances) and configuration (shape, size, and spatial organization) formed by these elements would reveal numerous functions (climate regulation, water infiltration, soil productivity, biodiversity, etc.) (Wu 2012). Therefore, the landscape functions were classified to provide a baseline for open green space system planning. In particular, a classification of functions that would allow the production, development, restoration and integration of open green spaces of certain qualities (forests, agricultural areas, recreational areas, etc.) was developed. Thus, the functions created by the inanimate elements of the landscape were called the "regulation function", the functions created by living elements were called "habitat function", and the functions provided by the landscape elements with cultural and heritage values were called the "cultural function." This classification was based on the studies by Hobbs (1997), De Groot (2006) and Willemen et al. (2008) (Fig. 2).

\section{Regulation function}

This function actually is the basis of life support systems. Thus, the survival of biota essentially depends on the functions of inanimate elements (geological structure, water, soil and climate) of the landscape. Measurement of the functions of these systems in natural or cultural landscapes is decisive in conservation, development or restoration

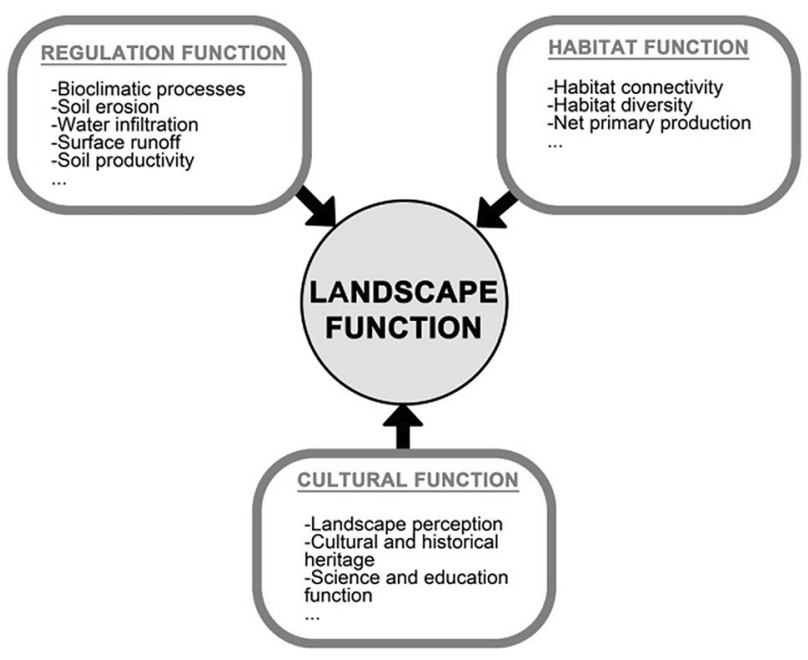

Fig. 2 The landscape function components decisions in open green space system planning for that area.

\section{Habitat function}

Even when the regulation function is high in a landscape, it may not provide a basis for the adequacy of the elements that determine the habitat function such as habitat diversity, habitat connectivity, and net primary production. Thus, it is necessary to determine the internal function level of a habitat.

\section{Cultural function}

Furthermore, the perception of the landscape based on the conceptual content, scientific importance, historical and cultural heritage values of the landscape determine the preservation and sustainability in open green space system planning. Thus, it is necessary to determine the cultural function levels and the living and inanimate landscape components.

Finally, these three functions and spaces with high or low landscape functions are determined and decisions to enforce the high-level relationship between open green spaces and urban areas such as maintaining spaces with high landscape function as open green spaces, the development of spaces with low landscape function, or restoration of these to a certain open green space typology, and proposing an ecological corridor to improve their connectivity when necessary.

\section{Definition of urban character}

The multi-dimensional conceptual content of landscape (spatial-temporal processes) indicates various processes that determine both concepts of open green space and urban. Landscape not only refers to different ecosystems (ecological processes), but also includes the concept of landform, earth surface processes and process relationships (Swanson et al. 1988; Renwick 1992). Geomorphic processes that represent the mechanical transport of organic and inorganic materials produced by tectonic, climatic and biotic factors define the land surface (Swanson et al. 1988). Geomorphological structure does not only affect the landscape design, but also the urbanization and urban sprawl, urban distribution and development (industry, tourism, etc.) (Guo et al. 2011; Mohapatra et al. 2014; Reynard et al. 2017). This interaction is bidirectional. Similarly, urbanization also has positive and negative, direct and indirect effects on geomorphology (Thornbush 2015), and these effects contribute to the development of planning policies (Adeli and Khorshiddoust 2011). Geomorphology, the presence of fertile soil, availability of transportation, proximity to raw materials, the presence of water, natural touristic landmarks shape the cities and provides a character. In this sense, it is decisive. 
A certain spatial urban pattern emerges due to the geomorphological structure under the influence of natural and cultural processes. This spatial pattern also corresponds to a sectoral design (housing, industry, agriculture, transportation, etc.). Here, the landscape, which is also determined by geomorphology, is replaced by the landscape transformed due to the anthropogenic impact. Landscape represents the geomorphological and anthropogenic processes that transform it (Price et al. 2011). The formation of cities is also a reflection of these processes. So much so that anthropogenic effects (of population and land use) are more determinant when compared to the geomorphological effects in urban open green space planning. For example, the process of the transformation of natural landscapes by industrial zones (or industrial metabolism) could be determined as a more effective geological and geomorphological agent when compared to the transformation of the landscape by a stream (Dougles and Lawson 2000). The main element of anthropogenic effect is population. Based on the current state of the cities, it could be observed that the concept of "city" was not sufficient, and instead, concepts such as "megapolis" and "urbanregion/city-region" and "conurbation" are used for cities of different scale (Lang and Knox 2009; Sorensen 2019). Thus, different densities of population transform both the physical and sectoral urban development based on the supply and demand. Therefore, urban character is defined by the population, geomorphology and sectoral structure (Fig. 3).

Urban character could directly affect the open green space requirements or policies. For example, the population of Málaga (Spain) and Dortmund (Germany) is approximately 590.000 in 2020 (World Population Review 2020). However, when analyzed based on the dominant land cover and sectoral structure, it could be suggested that Dortmund is

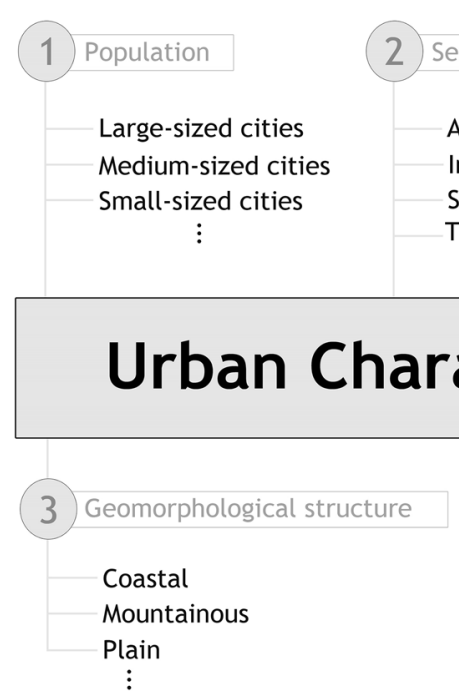

Fig. 3 Three main components that define the urban character an industrial city and Málaga is an agricultural city. Thus, an open green space planning only based on per capita open green space may ignore the open green space contribution of agricultural areas to the city and the relatively negative effect of the industry in the other. Similarly, Madrid (8.028 $\left.\mathrm{km}^{2}\right)$ and Ávila $\left(8.050 \mathrm{~km}^{2}\right)$ are neighbors in Spain and have similar surface areas, while the population of Madrid was about 6.66 million and that of Ávila was about 157.000 in 2019. The number of people per square kilometer was 830 in Madrid in 2019, while the same figure was 19.5 in Ávila (City Population 2020). Especially in Madrid, where the population density per square kilometer was about 42 times higher, it would be accurate to plan open green spaces based on different goals and strategies due to population density and the occupancy rate.

Also, two cities on the Black Sea coast in Turkey with similar population, Düzce (392.166) and Kastamonu (379.405) were analyzed based on the geomorphological criteria (Turkish Statistical Institute 2020). It was observed that Düzce was built on lowlands and is an agricultural city due to intensive agricultural activities. Kastamonu, on the other hand, was built on a mountainous region where tourism activities are prominent due to the natural landscape and geomorphological structure. Despite similar populations, the fact that one is an agricultural city built on a plain and the other is a touristic city built on mountainous terrain offers key features that could determine the open green space system planning. Thus, urban characteristics such as flat or mountainous terrain or large size affect the landscape design (Dai et al. 2018). In this context, all components that are determined by natural and cultural landscape properties in various geographies, including geomorphology, sectoral structure and population, should be analyzed based on the particular geography, and to provide a basis for an active open green space system planning. In the process approach, the urban character determination should categorize the population in a descending order, geomorphology should be categorized as coastal, mountain, lowland cities, when a city reflects more than one geomorphological property, the advantages and disadvantages of this structure could be integrated with open green space system planning, and the contribution of the sectoral structure determined by the dominant land use or land cover to open green space planning or the removal of its disadvantages. The studies on "character" also serve as a bridge between ecology and urban planning (Breuste 2006).

\section{Determination of the degree of urbanization}

In addition to the urban character gradually determined by the geomorphological structure, sectoral structure and the population in natural, rural and urban landscapes, urban built environment, which is emphasized as the balance of 
occupancy and inoccupancy, leads to different densities in various urban regions, disrupting the occupancy and inoccupancy balance. Urbanization refers to the process of change in land cover based on density and/or sprawl. Here, the density refers to the density of people or buildings, and sprawl refers to the spread of relatively less dense suburban settlements, which are connected to high-density settlements in urban core with a transportation network, and formed as protrusions and scatters (Forman 2014). In other words, urban growth occurs in a way that increases continuity in the immediate vicinity of the urban core in the form of an "infill" or "axial" spatial pattern, or in a manner that increases discontinuity relatively far from the urban core in the form of "leapfrogging development or isolated patches" (Inostroza et al. 2013). Studies on urban form and sprawl have commonly discussed "concentric partitioning" (Jiao 2015; Keeratikasikorn 2018), and the hierarchy was generally defined as the urban core, the area of urban continuous pattern, the urban fringe, where the urban pattern becomes increasingly discontinuous and the rural areas (Schmitt and Henry 2000; Schmitt et al. 2006). This urban pattern expands from the center to the periphery in several cities (Schneider and Woodcock 2008). Urbanization is a complex process that creates heterogeneous landscapes, and these landscapes are observed due to the transformation of rural areas around urban cores into urban fringes (Antrop and Van Eetvelde 2000). However, it could be observed that the anthropogenic effects increase towards the urban core and all urban growth increase "fragmentation" along the core, fringe, and the rural area (Medley et al. 1995; Weng 2007). The heterogeneous distribution of built environment and population density from the center to the periphery is called "degree of urbanization" (Antrop 2004; Weng 2007). The concept is particularly employed as a foundation in studies on urban landscape (Huang et al. 2010; Su et al. 2011; Calegaro-Marques and Amato 2014) and green space (Cho et al. 2008; Qureshi et al. 2010). The urban core includes open green spaces with high rate of impermeable surfaces, high-density land use, and relatively intensive urban recreation, urban fringe includes low density and scattered residential areas, wide open green spaces such as urban forests, agricultural land, golf courses and natural areas, forming a transition zone between the built environment and the countryside. Urban fringe includes rural areas with high agricultural operations (Dijkstra and Poelman 2012; Ravetz et al. 2013). In 2010, the European Commission initiated the "Global Human Settlement" project and classified the cities as urban core, urban fringe, rural fringe/area based on the population size and built environment density with the method proposed by OECD (Dijkstra and Poelman 2012).

Since the urban fringe is a transition zone, it could be considered as vulnerable ecotones geomorphologically (Guo et al. 2011). Furthermore, the growing and spreading city essentially transforms the neighboring agricultural lands and forests in the urban fringe into built environment; thus, it is very important to preserve the open green spaces with strategic significance (Xiao-jun 2001). However, the inhabitants of the urban core are advantageous when compared to those living in rural and suburban areas based on the availability of recreational services ( $\mathrm{Li}$ et al. 2013). Thus, the process approach to open green space system planning could include targets and strategies for each degree of urbanization such as the development of roof gardens based on the urban core density, the use of vacant lots as parks, employment of agricultural areas and forests as green belts to control growth in the urban fringe, emphasizing the recreational functions for those living in this zone, and preservation of open green spaces that would sustain rural character in the urban fringe.

\section{Definition and classification of open green spaces}

The most important stage of open green space guideline development is the definition of the open green spaces, which would ultimately determine all stages in the process approach. Studies in the literature included several definitions of open green spaces and many classifications based on these definitions. It is necessary to determine a definition based on the purpose to determine the associated classification. In the study, the concept of open green space is determined as all spaces excluding the indoor spaces and buildings without a roof garden. However, it should be noted that open green spaces could even be built in closed spaces/ buildings as roof gardens. Thus, the phrase "without a roof garden" was used in the definition. Furthermore, the definition of open green spaces did not include a distinction based on the ownership (public-private), to achieve a comprehensive definition. Because, when the definition is comprehensive, more types of open green spaces and a larger area could be included in planning and strategies and standards could be developed to ensure the utilization of these spaces for ecological, recreational, etc., purposes. Furthermore, the concept of "open green space" was adopted instead of only the concept of "open space" or "green space" to prevent the inclusion of open spaces without green spaces in the urban zone and to emphasize the significance of vegetative/permeable urban surfaces in the developed process approach. Thus, Table 1 was developed to present a comprehensive classification.

During the development of the classification presented in Table 1, the ecological, spatial, etc., functions of open green spaces, and the fulfillment of the recreational requirements of urban residents and urban public space requirements were stipulated. The significance of including permeable surfaces in the planning and design of functional open green spaces with a specific function, and the integration of the open green spaces with private ownership within recreational and 


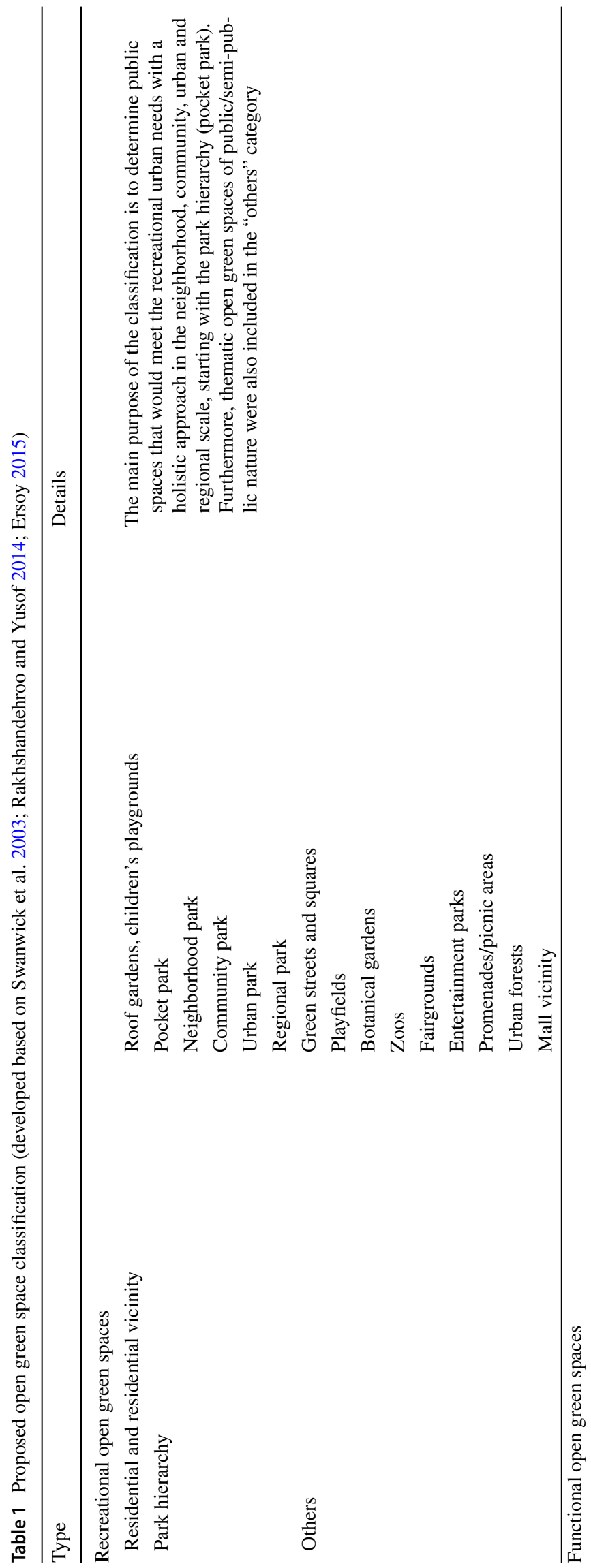




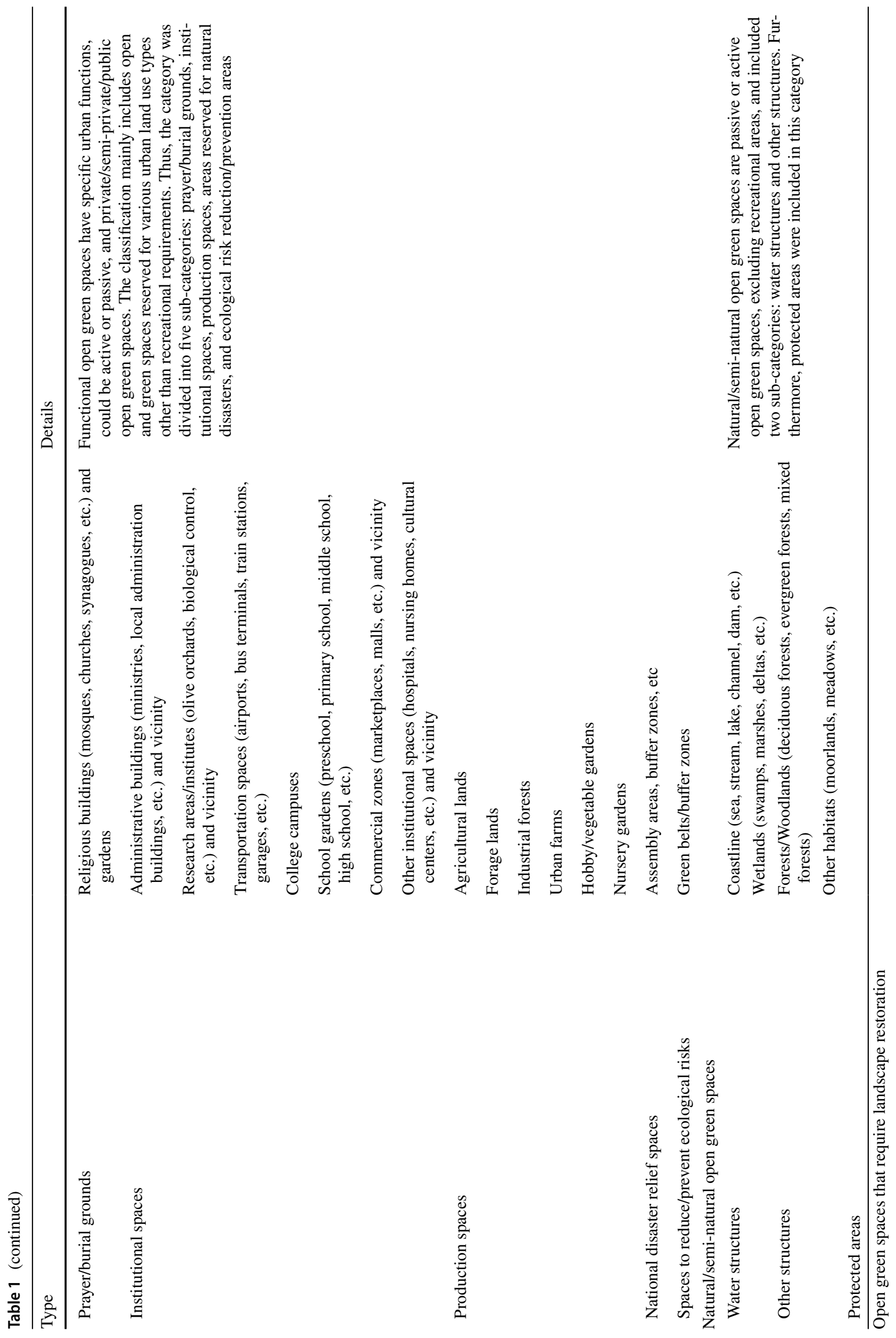




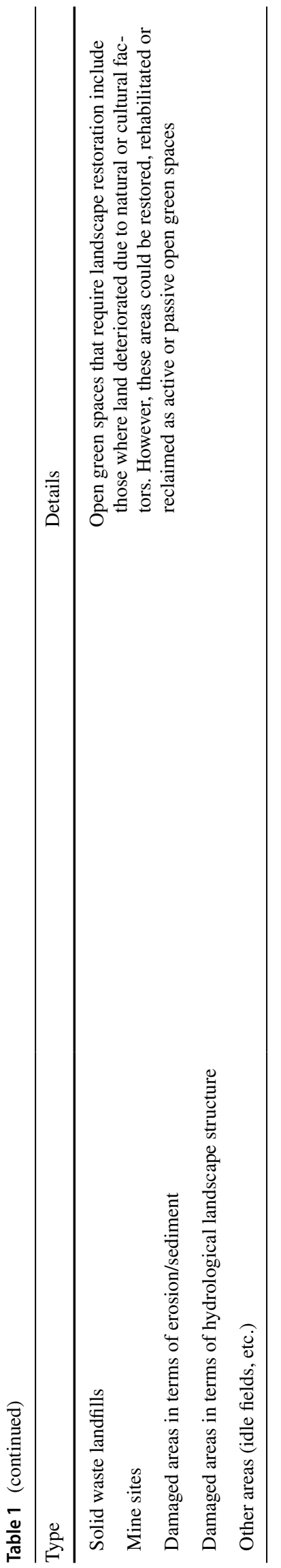

ecological functions were prioritized. Natural/semi-natural areas were categorized as "conservation areas" when there was no different requirement, and open green spaces that require landscape restoration were classified as "restoration, rehabilitation, reclamation" areas. The classification also aimed to develop a single language for plan legends in future spatial planning studies.

\section{Determination of open green space standards}

The population factor does not determine the open green space requirement only due to its impact on urban density. The inhabitants also have recreational needs. Because, the urban character and the spatial pattern created by the urban density (more construction, more impermeable surfaces, more industrialization, etc.) could weaken the nature-human relationship as mentioned above. On the other hand, it was reported that contact with nature (or urban greens) contributes to human health, and the contact would be possible with active participation in natural environments and participation could only be possible with the recreational use of urban open green spaces (Soga et al. 2015; Ekkel and de Vries 2017). Thus, universal access to open green spaces with an adequate size and an equal distribution throughout the urban space is important (Hillsdon et al. 2006; Yang et al. 2015). The adequate size and accessibility of open green spaces is not only associated with recreational functions. In addition, these attributes also help prevention and relief of disasters due to both ecological and social factors (Fan et al. 2012; Li 2014; Feng et al. 2015). Thus, although the determination of "minimum standards" for open green spaces has been frequently used to ensure public health and fair distribution of environmental benefits, this approach lacks specificity in frequency, type, or proximity (Kimpton 2017). In the literature, these standards were scrutinized in five categories: population-ratio (per capita space), area-percentage, catchment area (service area/distance), facility specification, and local standards (Veal 2013). The standards were developed in the present study based on the availability of the adequate size, accessibility, and equal spatial distribution of open green spaces in the city based on a certain hierarchy. Thus, certain standards were developed based on the park hierarchy detailed in the previous section to meet urban recreational and public space requirements and to allow access to recreational open green spaces for all, adequate size. For these standards to meet the specified conditions, they were determined based on $\mathrm{m}^{2} /$ capita, service radius, and size $\left(\mathrm{m}^{2}\right)$ (Table 2). In the park hierarchy, the size of the park increases with the distance between the settlement or housing and the park increases due to the addition of new types.

In addition to the recreational requirements, the assembling and shelter area functions, especially during and after disasters, were also included in the standards and the 
Table 2 Recreational standards for open green spaces (based on Veal 2013; Liu 2015; Cohen et al. 2016; Labuz 2019)

\begin{tabular}{llll}
\hline Park hierarchy & $\left(\mathrm{m}^{2} /\right.$ capita $)$ & $\begin{array}{l}\text { Service radius } \\
(\mathrm{m})\end{array}$ & Area $\left(\mathrm{m}^{2}\right)$ \\
\hline Pocket Park & - & - & $<4.000$ \\
Neighborhood & $<5$ & $<1.500$ & $8.000-20.000$ \\
$\quad$ Park & & & \\
Community Park & $5-10$ & $1.500-3.000$ & $40.000-100.000$ \\
Urban Park & 10 & $5.000-10.000$ & $200.000-800.000$ \\
Regional Park & $15-20$ & $>15.000$ & $>1.000 .000$ \\
\hline
\end{tabular}

Table 3 Disaster and post-disaster standards for open green spaces (based on Fan et al. 2012; JICA 2002; Zhu et al. 2016)

\begin{tabular}{llll}
\hline Shelter Type & $\left(\mathrm{m}^{2} /\right.$ capita $)$ & $\begin{array}{l}\text { Service } \\
\text { radius } \\
(\mathrm{m})\end{array}$ & Area $\left(\mathrm{m}^{2}\right)$ \\
\hline $\begin{array}{l}\text { Emergency (neighborhood } \\
\text { scale) }\end{array}$ & 1.5 & 300 & $100-5000$ \\
$\begin{array}{l}\text { Temporary (urban scale) } \\
\text { Long-Term (regional scale) }\end{array}$ & 2.5 & 1000 & $5000-10.000$ \\
\hline
\end{tabular}

standards were determined based on $\mathrm{m}^{2} /$ capita, service radius, and size $\left(\mathrm{m}^{2}\right)$ (Table 3$)$.

\section{Results}

Urban and regional natural systems are important for the city and its residents, and while these systems are relatively overlooked in urban planning, planners do not consider the most important ecological and environmental roles of the open green space system in planning due to the lack of a comprehensive and systematic approach to green space properties (Wang 2009). However, the urban quality depends on the planning, design, management, and preservation of urban open green spaces (Haq 2011). Because the open green space system is one of the basic spatial tools for sustainability. Therefore, the benefits of the open green space system for sustainability could be categorized as ecological, social and economic groups and various sub-topics could be developed under these categories. The present study aimed to propose a process approach that included the stages which could spatialize the benefits of the open green space system. Since open green spaces could be in different sizes and could be articulated to the city, the functions of open green spaces would differ based on size, location and quality within the city. The main driving factor is scale. Thus, the present study aimed to construct a conceptual framework where top-down and bottom-up approaches that reflect the functions of open green spaces, starting from the city and its hinterland, up to the building scale, could feed each other. Although it seemed that a top-down planning approach was adopted based on "evaluation of landscape function, definition of urban character, determination of degree of urbanization" stages in the process approach, a bottom-up approach that would guide the other stages on access and size was also supported.

The relationship between the spatial planning and process approach to open green space system planning is presented in Fig. 4. Establishing the relationship between the five-stage model and upper and lower scale plans would provide a road map for decision makers and implementers in the development of urban open green space system plans. Initially, national open green space policies and regional open green space strategies, and landscape functions in upper scale regional and metropolitan plans would support the development of the backbone of the urban open green space system. This approach would provide a holistic analysis especially based on the location of the city within the region and its relations with other cities and land use (forest, agriculture, protected areas, etc.). The urban character and the degree of urbanization, which also affect the urban structural plans, would play a significant role in urban open green space system plans at the lower scale. Landscape function analyzes that would be conducted at this scale will be used in the creation or development of the urban open green space system plan. On the other hand, the open green space conceptual framework could be reflected in planning decisions based on the open green space classification, allowing spatialization of areas in adequate quantities based on the open green space standards. Furthermore, association of other urban strategies (urban health, local development, urban biodiversity, transportation, urban resilience, etc.) in the development of plan decisions would also benefit the residents and allow them to internalize all processes and implementation of the plans with less resistance.

\section{Discussion}

The form of urbanization affects the sustainability of the nature-human relationship. The open green space stock, which are an extension of the landscape, based on the system approach, and intertwined within the cities, is a method to improve the relationship between humans and nature. According to Whyte (1968), connection between the open green spaces leads to a much better whole than the sum of the parts.

The open green space utilization varies in previous studies. Previous studies were conducted on the ecologi$\mathrm{cal}$, recreational, disaster management significance of open green space system planning (Kong et al. 2010; Bilgili and Düğüner 2012; Fei et al. 2020), as well as quantitative (Van Dillen et al. 2012), qualitative (Lee and Maheswaran 2011), accessibility (Van Herzele and Wiedemann 2003), and 
Fig. 4 The relations between the proposed urban open green space system process approach and other spatial plans

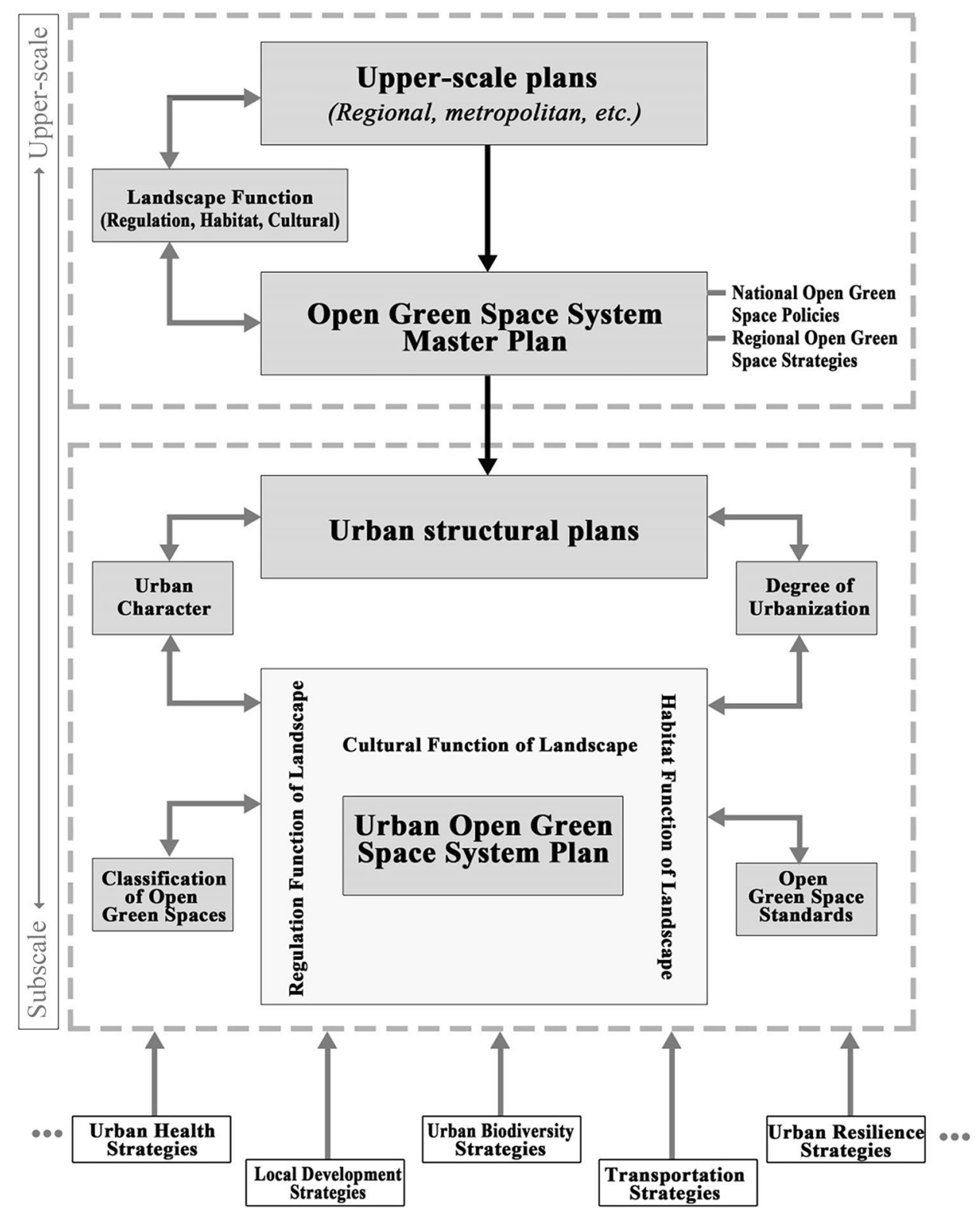

connectivity (Rudd et al. 2002) attributes. However, it was reported that even the most common planning models tend to focus on a specific issue such as recreation and/or conservation, and none were universally applicable to all functions and requirements (Maruani and Amit-Cohen 2007). Thus, there was a need for a new approach that would allow a systemic and multifunctional planning of open green spaces. Thus, development of a "landscape" based approach, would allow a holistic analysis of the relationship between urban systems, which are the extension of the landscape, and open green space system. Because landscape reflects a holistic entity where natural and human processes are combined and economic, social and ecological goals could be balanced in the pursuit of sustainable development (Selman 2006). Several studies defined integrated social and ecological systems as a ecological and environmental sustainability planning instrument (Ndubisi 2002; Botequilha Leitão and Ahern 2002; Brauch 2008; Estoque and Murayama 2013) and adopted the landscape concept that describes integrated social and ecological systems and improve the implementation of sustainable development and sustainability policies (Axelsson et al. 2011).

Certain studies mentioned the economic benefits of open green spaces (Heidt and Neef 2008; Van Zoest and Hopman 2014), open green spaces were the subject of "economic valuation" (Brander and Koetse 2011; Czembrowski and Kronenberg 2016) and the monetary equivalent of the benefits of open green spaces were scrutinized (Leng et al. 2004; Chiabai et al. 2009; Silvennoinen et al. 2017). In a study, the iconic green infrastructure Central Park was evaluated 
as a case study and 'holistic valuation' was developed as a method for determining the minimum value of ecosystem services obtained from urban parks. In the study, it is stated that the high value for Central Park is due to the interaction of social, natural, human and built capital (Sutton and Anderson 2016). However, in certain others, a concern that such approaches would commodify/had commodified ecosystems and components with the excuse of "conservation" and even gradually led to the commodification of nature was mentioned (McCauley 2006; Robertson 2006; GómezBaggethun and Ruiz-Pérez 2011; Kill 2014). Although there are studies that argued the opposite view in terms of the ecosystem services (Costanza 2006; Chen et al. 2010), the economic benefits of open green spaces were excluded from the present the process approach since the present study shared the above-mentioned concern. According to Millennium Assessment (2003) ecosystem services are grouped into four categories: "provisioning, regulating, supporting and cultural" and the concept is defined in the context of the benefits and goods that humans obtain from ecosystem functions. Therefore, the concept draws an anthropocentric framework and excludes the intrinsic value of nature and its components (Sagoff 2008; Redford and Adams 2009; Silvertown 2015). Ecosystems are only considered in the context of their benefits to humans and are commodified when necessary. In some studies, the concept of green infrastructure is directly integrated with ecosystem services (Tzoulas et al. 2007; Ajrina and Kustiwan 2019). Whereas green infrastructure is used to describe interconnected open green spaces (Wong 2010). In other words, it defines a systemic structure that approaches the ecosystem and landscape holistically. Therefore, in this study, the concept of landscape functions was preferred instead of ecosystem services, and the functions of the landscape were evaluated in the context of biota (not only humans) in a systemic framework, and the concept of ecosystem services was avoided.

Furthermore, the standards on the functions of open green spaces such as assembling-shelter and recreational-meeting facilities were limited. The scope of these standards can also be expanded based on disaster and recreation facilities, and also ecological standards such as "Biotope Area Factor" (Kazmierczak and Carter 2010), "Biological Activity Rate" (Takács et al. 2014), "Green Plot Ratio" (Ho et al. 2014), and providing a common language for the improvement of permeable surfaces by ensuring the sustainability of urban green spaces, etc., could be developed. Similarly, the proposals reflected in landscape function, urban character, degree of urbanization sections could be expanded or the process approach could be developed by including new sections. However, during the development of the process approach stages in the present study, a common framework applicable to every city was preferred. More specific or flexible content could be provided for a particular geography.
On the other hand, the phenomenon of climate change is another factor that reveals the risk of natural disasters (Kim et al. 2016; Carter et al. 2018; Lennon et al. 2018). In this context, it is necessary to develop open green space system strategies for natural disasters that may occur. One of the most important components in adapting and transforming urban spaces, especially in the context of flood risk reduction, is green infrastructure (Schubert et al. 2017; Lennon et al. 2018; Thorne et al. 2018). In addition to the earthquake, open green spaces are also used for reasons such as reducing the long-term effects of inadequate shelter after floods (Alavi et al. 2021) or establishing a fire assembly point in case of emergency evacuation to increase industrial safety (Chanthakhot and Ransikarbum 2021). Therefore, it is very critical to develop open green space system strategies/standards such as green infrastructure in the planning of disaster-resilient cities.

One of the most critical elements to be considered in the planning of the open green space system is the consequences of the COVID-19 pandemic process. The COVID19 pandemic has led us to highlight current urban planning and design issues that have failed to address the scarcity of green space (Ahmadpoor and Shahab 2021). Various studies conducted during the quarantine period due to the COVID-19 pandemic have found important results linking physical and mental health with urban nature/green spaces (Burnett et al. 2021; Lu et al. 2021). However, this process has also caused the desire to spend more time in the green space to change significantly among the society (Ugolini et al. 2020; Berdejo-Espinola et al. 2021). In addition, green spaces that the society cannot benefit from adequately are not preferred in terms of recreational use (Ahmadpoor and Shahab 2021) and that the recreational activities in urban green spaces and the urban infrastructure that supports it (i.e., bicycle and walking paths) are an important coping mechanism during the global epidemic, is also indicated (Venter et al. 2021). The conclusion to be drawn from all these is that people prefer to encounter the nature or green space view and experience this nature or green space view in other parts of the city as soon as they step out of the dwelling they live in. This is possible with an open green space network that is associated with the city and its immediate surroundings. Another crucial factor is that this open green space network also coincides with the spatial standards required by the pandemic.

It could be suggested that the present process approach, which included certain stages that would cover and allow the implementation in all cities, adopted a systemic landscape approach, included urban character and structure, and could allow the construction of multi-functional open green spaces, would make significant contributions to open green space system policies by local-central administrations and future studies and the literature. 


\section{Conclusion}

The present process approach, which addressed the open green space system and urban systems as an extension of the landscape, offered a unique foundation for open green space planning. The focus of studies on open green spaces and open green space systems on certain issues revealed the necessity of studies with a more holistic approach to open green spaces within a multi-dimensional and multi-functional conceptual framework. The present study focused on the spatialization of multifunctionality of open green spaces, as well as creation of sustainable spaces and habitats by establishing a relationship between the city and landscape. Thus, landscape was selected as the basic concept, and open green spaces and urban systems were defined as a subsystem of the landscape system. To integrate urban systems and open green space systems, the analysis of the advantages and disadvantages of urban features and the density of the built environment based on open green space system policies, and the combination of the landscape and ecological and geomorphological processes were encouraged. Furthermore, the green space concept was scrutinized and classified with a content that overlaps with the concept of landscape with its broadest definition. Based on this classification, the standards that would ensure the development of accessible and fair urban spaces and disaster-sensitive urban spaces were determined. Thus, the qualitative, quantitative, connectivity and location context of open green spaces were analyzed with a holistic approach and a multi-dimensional framework (ecological, recreational and disaster oriented) was presented, emphasizing its integration with spatial planning.

\section{References}

Acharya G, Bennett LL (2001) Valuing open space and land-use patterns in urban watersheds. J Real Estate Finance Econ 22(2-3):221-237

Adeli Z, Khorshiddoust A (2011) Application of geomorphology in urban planning: case study in landfill site selection. Proc Soc Behav Sci 19:662-667. https://doi.org/10.1016/j.sbspro.2011. 05.183

Ahern J (1991) Planning for an extensive open space system: linking landscape structure and function. Landsc Urban Plan 21(12):131-145. https://doi.org/10.1016/0169-2046(91)90037-m

Ahmadpoor N, Shahab S (2021) Realising the value of greenspace: a planners' perspective on the COVID-19 pandemic. Town Plan Rev 92(1):49-56

Ajrina H, Kustiwan I (2019) From green open space to green infrastructure: the potential of green open space optimization towards sustainable cities in Bekasi City \& Regency, Indonesia. In: IOP conference series: earth and environmental science, vol 399, no 1, p 012130. IOP Publishing

Alabi MO (2020) Sustainable urban form and challenges of open space utilization, Akure, Nigeria as a case study. Int J Urban Sustain Dev 1-12
Alavi MS, Fallahi A, Mottaki Z, Aslani F (2021) Post-disaster sheltering process after the 2019 floods, in Golestan province, Iran. Int J Disaster Resil Built Environ

Alberti M (2008) Advances in urban ecology: integrating humans and ecological processes in urban ecosystems. Springer, New York

Antrop M (2004) Landscape change and the urbanization process in Europe. Landsc Urban Plan 67(1-4):9-26

Antrop M, Van Eetvelde V (2000) Holistic aspects of suburban landscapes: visual image interpretation and landscape metrics. Landsc Urban Plan 50(1-3):43-58

Aronson MF, Lepczyk CA, Evans KL, Goddard MA, Lerman SB, MacIvor JS, Vargo T et al (2017) Biodiversity in the city: key challenges for urban green space management. Front Ecol Environ 15(4):189-196. https://doi.org/10.1002/fee.1480

Axelsson R, Angelstam P, Elbakidze M, Stryamets N, Johansson KE (2011) Sustainable development and sustainability: landscape approach as a practical interpretation of principles and implementation concepts. J Landsc Ecol 4(3):5-30

Bakker MM, Govers G, van Doorn A, Quetier F, Chouvardas D, Rounsevell M (2008) The response of soil erosion and sediment export to land-use change in four areas of Europe: the importance of landscape pattern. Geomorphology 98(3-4):213-226. https://doi. org/10.1016/j.geomorph.2006.12.027

Barrett GW, Peles JD, Odum EP (1997) Transcending processes and the levels-of-organization concept. Bioscience 47(8):531-535. https://doi.org/10.2307/1313121

Baycan-Levent T, Nijkamp P (2009) Planning and management of urban green spaces in Europe: comparative analysis. J Urban Plan Dev 135(1):1-12

Benedict MA, McMahon ET (2006) Green infrastructure: smart conservation for the 21 st century. Sprawl Watch Clearinghouse Monograph Series, Washington, DC

Berdejo-Espinola V, Suárez-Castro AF, Amano T, Fielding KS, Oh RRY, Fuller RA (2021) Urban green space use during a time of stress: a case study during the COVID-19 pandemic in Brisbane, Australia. People Nat

Bilgili BC, Gökyer E (2012) Urban green space system planning. Landsc Plan 360

Botequilha Leitão A, Ahern J (2002) Applying landscape ecological concepts and metrics in sustainable landscape planning. Landsc Urban Plan 59(2):65-93. https://doi.org/10.1016/s0169-2046(02) 00005-1

Bowler DE, Buyung-Ali L, Knight TM, Pullin AS (2010) Urban greening to cool towns and cities: a systematic review of the empirical evidence. Landsc Urban Plan 97(3):147-155. https://doi.org/10. 1016/j.landurbplan.2010.05.006

Brander LM, Koetse MJ (2011) The value of urban open space: metaanalyses of contingent valuation and hedonic pricing results. $\mathbf{J}$ Environ Manag 92(10):2763-2773

Brauch HG (2008) Landscape ecology and environmental security: basic concepts and regional applications for the medit. In: Use of landscape sciences for the assessment of environmental security. Springer, Dordrecht, pp 21-42

Breuste J (2006) Urban development and urban environment in Germany. Geographer Delhi 49(2):1-14

Burnett H, Olsen JR, Nicholls N, Mitchell R (2021) Change in time spent visiting and experiences of green space following restrictions on movement during the COVID-19 pandemic: a nationally representative cross-sectional study of UK adults. BMJ Open 11(3): 044067

Byrne J, Sipe N (2010) Green and open space planning for urban consolidation-a review of the literature and best practice. Urban Research Program Issues Griffith University, Brisbane

Calegaro-Marques C, Amato SB (2014) Urbanization breaks up host-parasite interactions: a case study on parasite community ecology of rufous-bellied thrushes (Turdus rufiventris) along a 
rural-urban gradient. PLoS ONE 9(7):e103144. https://doi.org/ 10.1371/journal.pone. 0103144

Carter JG, Handley J, Butlin T, Gill S (2018) Adapting cities to climate change-exploring the flood risk management role of green infrastructure landscapes. J Environ Plan Manag 61(9):1535-1552

Chanthakhot W, Ransikarbum K (2021) Integrated IEW-TOPSIS and Fire Dynamics Simulation for Agent-Based Evacuation Modeling in Industrial Safety. Safety 7(2):47

Chen X, Lupi F, Vina A, He G, Liu J (2010) Using cost-effective targeting to enhance the efficiency of conservation investments in payments for ecosystem services. Conserv Biol 24(6):1469-1478

Chiabai A, Travisi C, Ding H, Markandya A, Nunes PA (2009) Economic valuation of forest ecosystem services: methodology and monetary estimates

Cho SH, Poudyal NC, Roberts RK (2008) Spatial analysis of the amenity value of green open space. Ecol Econ 66(2-3):403-416

City of Melbourne Administration (2012) Open space strategy planning for future growth https://www.melbourne.vic.gov.au/SiteCollec tionDocuments/open-space-strategy.pdf. Accessed 14 July 2018

City Population (2020) http://citypopulation.de/. Accessed 21 Nov 2020

Cohen DA, Han B, Nagel CJ, Harnik P, McKenzie TL, Evenson KR, Katta $S$ et al (2016) The first national study of neighborhood parks. Am J Prev Med 51(4):419-426. https://doi.org/10.1016/j. amepre.2016.03.021

Conway TM, Lathrop RG (2005) Alternative land use regulations and environmental impacts: assessing future land use in an urbanizing watershed. Landsc Urban Plan 71:1-15

Costanza R (2006) Nature: ecosystems without commodifying them. Nature 443(7113):749-749

Czembrowski P, Kronenberg J (2016) Hedonic pricing and different urban green space types and sizes: Insights into the discussion on valuing ecosystem services. Landsc Urban Plan 146:11-19

Dai E, Wang Y, Ma L, Yin L, Wu Z (2018) 'Urban-rural' gradient analysis of landscape changes around cities in mountainous regions: a case study of the Hengduan mountain region in Southwest China. Sustainability 10(4):1019

De Groot R (2006) Function-analysis and valuation as a tool to assess land use conflicts in planning for sustainable, multi-functional landscapes. Landsc Urban Plan 75(3-4):175-186. https://doi.org/ 10.1016/j.landurbplan.2005.02.016

Dijkstra L, Poelman H (2012) Cities in Europe the new OECD-EC definition. http://ec.europa.eu/regional_policy/sources/docgener/ focus/2012_01_city.pdf. Accessed 05 Aug 2018

Douglas I, Lawson N (2000) The human dimensions of geomorphological work in Britain. J Ind Ecol 4(2):9-33. https://doi.org/10. $1162 / 108819800569771$

Dunnet N, Swanwick C, Woolley H (2002) Improving urban parks, play areas and green spaces department for transport. Local Government and the Regions Publications. Sales Centre Cambertown House Goldthorpe Industrial Estate

Ekkel ED, de Vries S (2017) Nearby green space and human health: evaluating accessibility metrics. Landsc Urban Plan 157:214-220

Ersoy M (2015) Kentsel Planlamada Standartlar. Ninova yayıncılık, İstanbul

Estoque RC, Murayama Y (2013) Landscape pattern and ecosystem service value changes: Implications for environmental sustainability planning for the rapidly urbanizing summer capital of the Philippines. Landsc Urban Plan 116:60-72. https://doi.org/10. 1016/j.landurbplan.2013.04.008

Fan L, Xue S, Liu G (2012) Patterns and its disaster shelter of urban green space: empirical evidence from Jiaozuo city, China. Afr J Agric Res 7(7):1184-1191

Farina A (2008) Principles and methods in landscape ecology: towards a science of the landscape, vol 3. Springer Science \& Business Media
Fei W, Wu J, Shi Y, Chen Q (2020) Construction of disaster prevention capability evaluation framework of urban park system: methodology and its application in China. J Environ Eng Landsc Manag 28(1):9-19

Feng Y, Zhang L, Shao M, Meng Q (2015) Discussion on the construction of disaster prevention green infrastructure network planning. In: 2015 4th national conference on electrical, electronics and computer engineering. Atlantis Press

Forman RTT (1995a) Land Mosaics - the ecology of landscapes and regions. Cambridge University Press, Cambridge

Forman RT (1995b) Some general principles of landscape and regional ecology. Landsc Ecol 10(3):133-142

Forman RT (1987) The ethics of isolation, the spread of disturbance, and landscape ecology. In: Landscape heterogeneity and disturbance. Springer, New York, NY, pp 213-229

Forman RTT, Godron M (1986) Landscape ecology. Wiley, New York

Forman RT (2014) Urban ecology: science of cities. Cambridge University Press, Cambridge

Fuller RA, Irvine KN, Devine-Wright P, Warren PH, Gaston KJ (2007) Psychological benefits of greenspace increase with biodiversity. Biol Lett 3:390-394. https://doi.org/10.1098/rsbl.2007.0149

Golley FB (1987) Introducing landscape ecology. Landsc Ecol 1(1):1-3

Gómez-Baggethun E, Ruiz-Pérez M (2011) Economic valuation and the commodification of ecosystem services. Prog Phys Geogr 35(5):613-628. https://doi.org/10.1177/0309133311421708

Guo W, Li S, Zhu D (2011) Modern geomorphological environment research during rapid urbanization in Shenzhen east coastal zone. J Geogr Sci 21(2):372-384. https://doi.org/10.1007/ s11442-011-0851-8

Hall DL (1991) Landscape planning: functionalism as a motivating concept from landscape ecology and human ecology. Landsc Urban Plan 21(1-2):13-19. https://doi.org/10.1016/01692046(91)90029-1

Haq SMA (2011) Urban green spaces and an integrative approach to sustainable environment. J Environ Prot 2(05):601

Harding S (2000) Towards a renaissance in urban parks. In: Cultural trends, vol 35. Policy Studies Institute, London, pp 1-26

Heidt V, Neef M (2008) Benefits of urban green space for improving urban climate. In: Ecology, planning, and management of urban forests. Springer, New York pp 84-96

Hillsdon M, Panter J, Foster C, Jones A (2006) The relationship between access and quality of urban green space with population physical activity. Public Health 120(12):1127-1132

Ho KH, Orlenko I, Rengarajan S (2014) To develop landscape guidelines for application of Green Plot Ratio in Singapore. http:// www.ires.nus.edu.sg/newsletter2014/Issue1/issue1 content.pdf. Accessed 09 Aug 2018

Hobbs R (1997) Future landscapes and the future of landscape ecology. Landsc Urban Plan 37(1-2):1-9. https://doi.org/10.1016/ s0169-2046(96)00364-7

Huang D, Su Z, Zhang R, Koh LP (2010) Degree of urbanization influences the persistence of Dorytomus weevils (Coleoptera: Curculionoidae) in Beijing, China. Landsc Urban Plan 96(3):163-171

Inostroza L, Baur R, Csaplovics E (2013) Urban sprawl and fragmentation in Latin America: a dynamic quantification and characterization of spatial patterns. J Environ Manag 115:87-97

Jackson S, Hitchins D, Eisner H (2010) What is the systems approach? Insight 13(1):41-43. https://doi.org/10.1002/inst.201013141a

Jiao L (2015) Urban land density function: a new method to characterize urban expansion. Landsc Urban Plan 139:26-39

JICA (2002) The study on a disaster prevention/mitigation basic plan. In: Istanbul including microzonation. In: The republic of Turkey final report volume V September 2002 (Türkiye Cumhuriyeti İstanbul İli Sismik Mikro-Bölgeleme Dahil Afet Önleme/Azaltma Temel Planı Çalışması. Son Rapor Cilt V). Pacific Consultants International OYO Corporation 
Jim CY (2004) Green-space preservation and allocation for sustainable greening of compact cities. Cities 21(4):311-320

Jim CY, Chen SS (2003) Comprehensive greenspace planning based on landscape ecology principles in compact Nanjing city, China. Landsc Urban Plan 65(3):95-116

Kazmierczak A, Carter J (2010) Adaptation to climate change using green and blue infrastructure adatabase of case studies. http:// orca.cf.ac.uk/64906/1/Database_Final_no_hyperlinks.pdf. Accessed 09 Aug 2018

Keeratikasikorn C (2018) A comparative study on four major cities in Northeastern Thailand using urban land density function. GeoSpatial Inf Sci 21(2):93-101

Khalil R (2014) Quantitative evaluation of distribution and accessibility of urban green spaces (case study: City of Jeddah). Int J Geomai1cs Geosci 4(3):526-535

Kill J (2014) Economic valuation of nature. Rosa-Luxemburg-Stiftung, Bruxelas

Kim H, Lee DK, Sung S (2016) Effect of urban green spaces and flooded area type on flooding probability. Sustainability 8(2):134

Kimpton A (2017) A spatial analytic approach for classifying greenspace and comparing greenspace social equity. Appl Geogr 82:129-142. https://doi.org/10.1016/j.apgeog.2017.03.016

Kong F, Yin H, Nakagoshi N, Zong Y (2010) Urban green space network development for biodiversity conservation: identification based on graph theory and gravity modeling. Landsc Urban Plan 95(1-2):16-27. https://doi.org/10.1016/j.landurbplan.2009.11. 001

Labuz R (2019) Pocket park-a new type of green public space in Kraków (Poland). IOP Conf Ser Mater Sci Eng 471(11):112018

Lai CH, Huili Lin S (2017) Systems theory. In: The international encyclopedia of organizational communication, pp 1-18

Lang R, Knox PK (2009) The new metropolis: rethinking megalopolis. Reg Stud 43(6):789-802. https://doi.org/10.1080/0034340070 1654251

Lee AC, Maheswaran R (2011) The health benefits of urban green spaces: a review of the evidence. J Public Health 33(2):212-222

Leng PS, Yang XH, Su F, Wu B (2004) Economic valuation of urban greenspace ecological benefits in Beijing city. J Beijing Agric Coll 19(4):25-28

Lennon M, Scott M, O'Neill E (2018) Urban design and adapting to flood risk: the role of green infrastructure. In: Planning for climate change. Routledge, pp 263-272

Li S (2014) The development of disaster prevention green space in China. Landsc Archit Front 2(4):44-52

Li J, Li C, Zhu F, Song C, Wu J (2013) Spatiotemporal pattern of urbanization in Shanghai, China between 1989 and 2005. Landsc Ecol 28(8):1545-1565. https://doi.org/10.1007/s10980-013-9901-1

Li F, Sutton PC, Anderson SJ, Nouri H (2017) Planning green space in Adelaide city: enlightenment from green space system planning of Fuzhou city (2015-2020). Aust Plan 54(2):126-133. https:// doi.org/10.1080/07293682.2017.1345962

Liu S (2015) Urban park planning on spatial disparity between demand and supply of park service. In: 2015 3rd international conference on advances in energy and environmental science. Atlantis Press

Lu Y, Zhao J, Wu X, Lo SM (2021) Escaping to nature during a pandemic: a natural experiment in Asian cities during the COVID19 pandemic with big social media data. Sci Total Environ 777:146092

Lynch K (1981) A theory of good city form. M.I.T. Press, Cambridge

MacMahon JA, Phillips DL, Robinson JV, Schimpf DJ (1978) Levels of biological organization: an organism-centered approach. Bioscience 28(11):700-704. https://doi.org/10.2307/1307320

Marriott K (1999) Nothing is standard anymore. Aus. Leisure Manage

Maruani T, Amit-Cohen I (2007) Open space planning models: a review of approaches and methods. Landsc Urban Plan 81(12):1-13. https://doi.org/10.1016/j.landurbplan.2007.01.003
McCauley DJ (2006) Selling out on nature. Nature 443(7107):27-28

Medley KE, McDonnell MJ, Pickett STA (1995) Forest-landscape structure along an urban-to-rural gradient*. Prof Geogr 47(2):159-168. https://doi.org/10.1111/j.0033-0124.1995. 00159.x

Mejía CV, Shirotova L, de Almeida IFM (2015) Green infrastructure and german landscape planning: a comparison of approaches. Urbani Izziv 26:S25-S37

Mell I (2017) Green infrastructure: reflections on past, present and future praxis. Landsc Res 42(2):135-145

Mell I (2020) The impact of austerity on funding green infrastructure: a DPSIR evaluation of the Liverpool Green \& Open Space Review (LG\&OSR), UK. Land Use Policy 91:104284

Millennium Assessment (2003) Ecosystems and human well-being: a framework for assessment. Millennium ecosystem assessment series. Island Press, Washington, DC

Mohapatra SN, Pani P, Sharma M (2014) Rapid urban expansion and its implications on geomorphology: a remote sensing and GIS based study. Geogr J

Mpofu TP (2013) Environmental challenges of urbanization: a case study for open green space management. Res J Agric Environ Manag 2(4):105-110

Ndubisi F (2002) Managing change in the landscape: a synthesis of approaches for ecological planning. Landsc J 21(1):138-155. https://doi.org/10.3368/lj.21.1.138

Pauleit S, Slinn P, Handley J, Lindley S (2003) Promoting the natural greenstructure of towns and cities: English nature's accessible natural greenspace standards models. Built Environ 292:157-170

Peters K, Elands B, Buijs A (2010) Social interactions in urban parks: stimulating social cohesion? Urban for Urban Green 9(2):93-100

Pickett STA, Cadenasso ML (1995) Landscape ecology: spatial heterogeneity in ecological systems. Science 269(5222):331-334. https://doi.org/10.1126/science.269.5222.331

Pickett STA, Burch WR Jr, Dalton SE, Foresman TW, Grove JM, Rowntree R (1997) A conceptual framework for the study of human ecosystems in urban areas. Urban Ecosyst 1:185-199

Price SJ, Ford JR, Cooper AH, Neal C (2011) Humans as major geological and geomorphological agents in the Anthropocene: the significance of artificial ground in Great Britain. Philos Trans R Soc A Math Phys Eng Sci 369(1938):1056-1084. https://doi.org/ 10.1098/rsta.2010.0296

Qureshi S, Breuste JH, Lindley SJ (2010) Green space functionality along an urban gradient in Karachi, Pakistan: a socio-ecological study. Hum Ecol 38(2):283-294

Rakhshandehroo M, Yusof M (2014) Establishing new urban green spaces classification for Malaysian cities. In: İçinde IFLA Asia Pacific congress. Kuching, pp 1-13

Randolph J (2004) Environmental land use planning and management. Island Press, Washington, DC

Ravetz J, Fertner C, Nielsen, Thomas AS (2013) The dynamics of peri-urbanization. In: Peri-urban futures: scenarios and models for land use change in Europe. Springer Publishing Company, pp 13-45

Redford KH, Adams WM (2009) Payment for ecosystem services and the challenge of saving nature. Conserv Biol 23:785-787

Renwick WH (1992) Equilibrium, disequilibrium, and nonequilibrium landforms in the landscape. Geomorphology 5(3-5):265-276

Reynard E, Pica A, Coratza P (2017) Urban geomorphological heritage. An overview. Quaest Geogr 36(3):7-20

Robertson MM (2006) The nature that capital can see: science, state, and market in the commodification of ecosystem services. Environ Plan D Soc Space 24(3):367-387. https://doi.org/10.1068/ d3304

Rudd H, Vala J, Schaefer V (2002) Importance of backyard habitat in a comprehensive biodiversity conservation strategy: a connectivity analysis of urban green spaces. Restor Ecol 10(2):368-375 
Sagoff M (2008) On the economic value of ecosystem services. Environ Values 17(2):239-257

Sandström UG (2002) Green infrastructure planning in urban Sweden. Plan Pract Res 17(4):373-385

Sandström UG, Angelstam P, Khakee A (2006) Urban comprehensive planning-identifying barriers for the maintenance of functional habitat networks. Landsc Urban Plan 75(1-2):43-57

Schmitt B, Henry MS (2000) Size and growth of urban centers in French labor market areas: consequences for rural population and employment. Reg Sci Urban Econ 30(1):1-21

Schmitt B, Henry MS, Piguet V, Hilal M (2006) Urban growth effects on rural population, export and service employment: evidence from eastern France. Ann Reg Sci 40(4):779-801

Schneider A, Woodcock CE (2008) Compact, dispersed, fragmented, extensive? A comparison of urban growth in twenty-five global cities using remotely sensed data, pattern metrics and census information. Urban Stud 45(3):659-692

Schubert JE, Burns MJ, Fletcher TD, Sanders BF (2017) A framework for the case-specific assessment of Green Infrastructure in mitigating urban flood hazards. Adv Water Resour 108:55-68

Selman P (2006) Planning at the landscape scale. Routledge, New York

Silvennoinen S, Taka M, Yli-Pelkonen V, Koivusalo H, Ollikainen M, Setälä H (2017) Monetary value of urban green space as an ecosystem service provider: a case study of urban runoff management in Finland. Ecosyst Serv 28:17-27

Silvertown J (2015) Have ecosystem services been oversold? Trends Ecol Evol 30(11):641-648

Singh VS, Pandey DN, Chaudhry P (2010) Urban forests and open green spaces: lessons for Jaipur, Rajasthan India. Rajasthan State Pollution Control Board, Jaipurpp 1-18

Soga M, Yamaura Y, Aikoh T, Shoji Y, Kubo T, Gaston KJ (2015) Reducing the extinction of experience: association between urban form and recreational use of public greenspace. Landsc Urban Plan 143:69-75

Sorensen A (2019) Tokaido Megalopolis: lessons from a shrinking megaconurbation. Int Plan Stud 24(1):23-39. https://doi.org/10.1080/ 13563475.2018 .1514294

Ståhle A (2010) More green space in a denser city: Critical relations between user experience and urban form. Urban Design International 15(1):47-67

Su S, Jiang Z, Zhang Q, Zhang Y (2011) Transformation of agricultural landscapes under rapid urbanization: a threat to sustainability in Hang-Jia-Hu region, China. Appl Geogr 31(2):439-449

Sutton PC, Anderson SJ (2016) Holistic valuation of urban ecosystem services in New York City's Central Park. Ecosyst Serv 19:87-91

Swanson FJ, Kratz TK, Caine N, Woodmansee RG (1988) Landform effects on ecosystem patterns and processes. Bioscience 38(2):92-98

Swanwick C, Dunnett N, Woolley H (2003) Nature, role and value of green space in towns and cities: an overview. Built Environ 29(2):94-106

Takács D, Varró D, Bakay E (2014) Comparison of different space indexing methods for ecological evaluation of urban open spaces. Appl Ecol Environ Res 12(4):1027-1048

Taylor L, Hochuli DF (2017) Defining greenspace: Multiple uses across multiple disciplines. Landsc Urban Plan 158:25-38

Thornbush M (2015) Geography, urban geomorphology and sustainability. Area 47(4):350-353

Thorne CR, Lawson EC, Ozawa C, Hamlin SL, Smith LA (2018) Overcoming uncertainty and barriers to adoption of Blue-Green Infrastructure for urban flood risk management. J Flood Risk Manag 11:S960-S972

Threlfall CG, Ossola A, Hahs AK, Williams NS, Wilson L, Livesley SJ (2016) Variation in vegetation structure and composition across urban green space types. Front Ecol Evol 4:66

Turkish Statistical Institute (2020) http://www.turkstat.gov.tr/Start.do. Accessed 11 June 2020
Turner MG (1989) Landscape ecology: the effect of pattern on process. Annu Rev Ecol Syst 20(1):171-197

Tzoulas K, Korpela K, Venn S, Yli-Pelkonen V, Kaźmierczak A, Niemela J et al (2007) Promoting ecosystem and human health in urban areas using green infrastructure: a literature review. Landsc Urban Plan 81:167-178. https://doi.org/10.1016/j.landurbplan.2007.02. 001

Ugolini F, Massetti L, Calaza-Martínez P, Cariñanos P, Dobbs C, Ostoić SK, Sanesi G et al (2020) Effects of the COVID-19 pandemic on the use and perceptions of urban green space: an international exploratory study. Urban for Urban Green 56:126888

United Nations (2012) World urbanization prospects: the 2014 revision. CD-ROM Edition

Van Dillen SM, de Vries S, Groenewegen PP, Spreeuwenberg P (2012) Greenspace in urban neighbourhoods and residents' health: adding quality to quantity. J Epidemiol Community Health 66(6):e8

Van Herzele A, Wiedemann T (2003) A monitoring tool for the provision of accessible and attractive urban green spaces. Landscape Urban Plan 63(2):109-126

Van Zoest J, Hopman M (2014) Taking the economic benefits of green space into account: the story of the Dutch TEEB for Cities project. Urban Clim 7:107-114. https://doi.org/10.1016/j.uclim.2014.01. 005

Veal AJ (2013) Open space planning standards in Australia: in search of origins. Aust Plan 50(3):224-232

Venter ZS, Barton DN, Gundersen V, Figari H, Nowell MS (2021) Back to nature: Norwegians sustain increased recreational use of urban green space months after the COVID-19 outbreak. Landsc Urban Plan 214:104175

Vieira J, Matos P, Mexia T, Silva P, Lopes N, Freitas C, Pinho P et al (2018) Green spaces are not all the same for the provision of air purification and climate regulation services: the case of urban parks. Environ Res 160:306-313

Wang XJ (2009) Analysis of problems in urban green space system planning in China. J for Res 20(1):79-82

Weng YC (2007) Spatiotemporal changes of landscape pattern in response to urbanization. Landsc Urban Plan 81(4):341-353

Willemen L, Verburg PH, Hein L, van Mensvoort MEF (2008) Spatial characterization of landscape functions. Landsc Urban Plan 88(1):34-43. https://doi.org/10.1016/j.landurbplan.2008.08.004

Wolch JR, Byrne J, Newell JP (2014) Urban green space, public health, and environmental justice: the challenge of making cities 'just green enough.' Landsc Urban Plan 125:234-244

Wong KK (2010) Urban open space system in northern Kowloon Peninsula: an emerging green infrastructure network in Hong Kong. Asian Geogr 27(1-2):13-28

World Health Organization (WHO) (2017) Urban green spaces: a brief for action. World Health Organization, Regional Office for Europe: Copenhagen

World Population Review (2020) https://worldpopulationreview.com/. Accessed 21 Nov 2020

Wu J (2008) Making the case for landscape ecology: an effective approach to urban sustainability. Landsc J 27(1):41-50. https://doi.org/10. $3368 / 1 \mathrm{j} .27 .1 .41$

Wu J (2009) Urban sustainability: an inevitable goal of landscape research. Landscape Ecol 25(1):1-4. https://doi.org/10.1007/ s10980-009-9444-7

Wu J (2012) Landscape ecology. Ecol Syst. https://doi.org/10.1007/9781-4614-5755-8_11

Xiao-jun W (2001) Type, quantity and layout of urban peripheral green space. J for Res 12(1):67-70. https://doi.org/10.1007/bf02856805

Yang J, Li C, Li Y, Xi J, Ge Q, Li X (2015) Urban green space, uneven development and accessibility: a case of Dalian's Xigang District. Chin Geogr Sci 25(5):644-656

Zhu C, Wang Y, Ren W, Luo I, Yin Y, Xie W, Liu W (2016) The planning of green spaces to prevent and avoid urban disasters in Dujiangyan. Int J Simul Syst Sci Technol 17(46):271-276 